\title{
Mammogenesis and changing prolactin receptor concentrations in the mammary glands of the tammar wallaby (Macropus eugenii)
}

\author{
Francesca Stewart* \\ CSIRO Division of Wildlife Research, PO Box 84, Lyneham, ACT 2602, Australia
}

\begin{abstract}
Summary. All 4 mammary glands of the tammar wallaby showed a steady increase in weight and prolactin receptor concentration during the luteal phase of the oestrous cycle to reach a peak at oestrus. Removal of the corpus luteum abolished this mammogenesis, while pregnancy, which in this species is a day or so shorter than the oestrous cycle, had no effect. This provides an explanation for the previous finding that pregnancy is not a necessary pre-requisite for lactation in marsupials and that nonpregnant animals will lactate very successfully, provided the suckling stimulus is applied at the correct stage of the oestrous cycle.

During lactation, only the gland supplying the teat to which the pouch young was attached developed and showed any further increase in prolactin receptors; the other 3 glands remained small and inactive. These results indicate the importance of the suckling stimulus and milk withdrawal on the initiation and maintenance of lactation.
\end{abstract}

\section{Introduction}

Macropodid marsupials (kangaroos and wallabies) are monovular and give birth to a single young weighing only $400-800 \mathrm{mg}$ which climbs unaided into its mother's pouch. Once inside the pouch, the young becomes firmly attached to one of the 4 teats. Only the mammary gland supplying this teat develops and lactates; the other 3 glands remain small and inactive. Lactation continues for as long as 10 months and weaning is a very gradual process with the young continuing to suck even after it has left the pouch permanently. In some species, a second young is born while the first young is still sucking from the teat to which it was originally attached as a neonate. The new-born young attaches to one of the 3 remaining teats which again initiates lactation only in the gland supplying this teat (Sharman, 1970). There are significant changes in milk composition during lactation in marsupials (Green, Newgrain \& Merchant, 1980) and it is possible for two different kinds of milk to be produced by the same animal in adjacent mammary glands (Sharman, 1970; Griffiths, McIntosh \& Leckie, 1972).

Another unusual feature of lactation in marsupials is that pregnancy does not appear to have any influence on the subsequent ability of the female to lactate. Experiments involving the transfer of neonatal pouch young of the same or different species have shown that, in contrast to eutherian mammals, female marsupials that have not undergone pregnancy before the suckling stimulus lactate as successfully as those that have experienced pregnancy. However, it would appear that the donor and recipient animals must be synchronized so that the recipient is at the stage of its oestrous

* Present address: A.R.C. Institute of Animal Physiology, Animal Research Station, 307 Huntingdon Road, Cambridge CB3 0JQ, U.K.

(C) 1984 Journals of Reproduction \& Fertility Ltd 
cycle corresponding to the time at which it would give birth were it pregnant (Merchant \& Sharman, 1966). At this time, which varies from mid-cycle in the brush possum (Trichosurus vulpecula) to several days after oestrus in the swamp wallaby (Wallabia bicolor), the mammary glands are slightly enlarged and the teats are turgid (Sharman \& Calaby, 1964). It appears therefore that the hormonal changes taking place during the oestrous cycle initiate sufficient mammary gland development to enable lactation to be induced by the sucking stimulus of the new-born young alone and that pregnancy has little or no effect on this development.

In this study, the unusual features of marsupial lactation have been further investigated by measuring changes in mammary gland weights and mammary prolactin receptor concentrations in a small macropodid marsupial, the tammar wallaby (Macropus eugenii). The mammary glands were examined at regular intervals during lactation, the oestrous cycle and pregnancy and the data were related to the morphology of the glands and to circulating hormone levels. In addition, the effects of excision of the corpus luteum were examined to assess the role of the corpus luteum in stimulating the mammogenesis that occurs during the oestrous cycle.

\section{Materials and Methods}

Animals. All the tammar wallabies used in this study were from a breeding colony of animals originally obtained from Kangaroo Island, South Australia. The mammary glands were collected within a few minutes of death and the teats and extraneous connective tissue removed before weighing. The glands were then frozen at $-20^{\circ} \mathrm{C}$ if required for receptor measurements or fixed in Bouin's fluid if required for histology.

The suckled and unsuckled mammary glands were collected from a total of 35 tammar wallabies at various stages throughout lactation. All of these animals were carrying a single pouch young which meant that only one of the 4 glands in each animal was enlarged and producing milk. Most of these animals were killed for other experiments. The non-pregnant and pregnant animals were undergoing oestrous cycles and pregnancies respectively after 'reactivation' from a state of reproductive quiescence (Tyndale-Biscoe, Hearn \& Renfree, 1974). This was achieved in lactating animals by removing the pouch young and in seasonally quiescent animals by a single injection of 2 mg bromocriptine (CB154; Sandoz Australia Pty Ltd)/kg body weight (Tyndale-Biscoe \& Hinds, 1983).

Since the female tammar wallaby generally returns to oestrus 9-18 days after removal of the corpus luteum (Tyndale-Biscoe \& Hawkins, 1977) it was possible to examine the effect of the preceding luteal phase on mammary development seen at oestrus in these animals. The corpus luteum was removed from 8 non-pregnant tammar wallabies under general anaesthesia with thiamylal sodium (Surital; Parke Davis) and the mammary glands of the 3 that returned to oestrus were collected the day they returned to oestrus. Oestrus was detected by the presence of a mating plug (Tyndale-Biscoe \& Rodger, 1978).

Receptor measurements. The frozen mammary glands were thawed, homogenized in cold preparation buffer ( $25 \mathrm{~mm}$-Tris- $\mathrm{HCl}, 0.3 \mathrm{M}$-sucrose, $\mathrm{pH} \mathrm{7.4)}$ using an Ultra-Turax tissue homogenizer (Janke \& Kunkel KG) and filtered through 2 layers of butter muslin. The resulting suspension was centrifuged at $15000 \mathrm{~g}$ for $30 \mathrm{~min}$ and the tissue pellet resuspended in assay buffer ( $25 \mathrm{~mm}$-Tris- $\mathrm{HCl}, 10 \mathrm{~mm}-\mathrm{MgCl}_{2}, 0.5 \%$ bovine serum albumin, $\mathrm{pH} 7 \cdot 6$ ) at a nominal concentration of $100 \mathrm{mg}$ wet tissue/ml. The supernatant was further centrifuged at $100000 \mathrm{~g}$ for $90 \mathrm{~min}$ and the resulting tissue pellet was resuspended in the same volume as the $15000 \mathrm{~g}$ pellet. The degree of binding of ${ }^{125} \mathrm{I}$-labelled ovine prolactin (NIH-P-S12) to the $15000 \mathrm{~g}$ and $100000 \mathrm{~g}$ fractions was assessed using previously described methods (Stewart \& Tyndale-Biscoe, 1982) and the results were added together for each sample. It was necessary to measure the binding to both fractions because, although the binding increased linearly with increasing amounts of tissue in each case, the relationship between the binding to each fraction was not always constant between samples. The methods 
employed here were based on those originally described by Sernia \& Tyndale-Biscoe (1979) who identified and characterized the tammar wallaby prolactin receptor in a number of tissues, including the lactating mammary gland. Sernia \& Tyndale-Biscoe (1979), using the same ovine prolactin preparation as was used in the present study, demonstrated the specificity of the receptor for prolactin. They demonstrated that while ovine and bovine prolactin readily displaced labelled ovine prolactin from these receptors, ovine $\mathrm{FSH}, \mathrm{LH}, \mathrm{GH}$ and TSH did not. The association constant $\left(K_{\mathrm{a}}\right.$ at $\left.23^{\circ} \mathrm{C}\right)$ of the mammary prolactin receptor was $9 \times 10^{8} \mathrm{l} / \mathrm{mol}$ (Sernia \& TyndaleBiscoe, 1979). In the present study, measurements were carried out both before and after the removal of bound prolactin with $3 \mathrm{M}-\mathrm{MgCl}_{2}$ (see Stewart \& Tyndale-Biscoe, 1982) and all results presented here are those determined after treatment with $\mathrm{MgCl}_{2}$.

The DNA content of the homogenates was measured using the colorimetric assay of Burton (1956) and the results are expressed as the amount of prolactin bound $/ \mu \mathrm{g} D \mathrm{DNA}$. In addition to measuring the DNA content of the fractionated homogenates, the total DNA content of mammary gland tissue was assessed in small samples taken at various stages during lactation. These samples were homogenized as for the receptor binding assay, but were not filtered through butter muslin before the DNA assay.

\section{Results}

\section{Mammary gland development and changes in prolactin binding during lactation}

Only the gland supplying the teat to which the pouch young was attached increased in size and produced milk during lactation (Text-fig. 1a). At parturition (Day 0 ) all 4 glands were similar in size and weighed about $1 \mathrm{~g}$ (range $0.7-0.9 \mathrm{~g}$ ). One week later the suckled gland was noticeably heavier $(1.3 \mathrm{~g}$; range $0 \cdot 8-2.0 \mathrm{~g})$ than at parturition while the unsuckled glands had regressed to a totally inactive state $(0.2 \mathrm{~g})$. The unsuckled glands remained at about $0.2 \mathrm{~g}$ throughout the very long lactating period while the suckled gland increased to about $36 \mathrm{~g}$ (range $27-42 \mathrm{~g}$ ) at Week 34 and had declined to around $20 \mathrm{~g}$ by Week 48 . The rapid growth phase of the suckled mammary gland up to Week 34 of lactation followed very closely the growth curve of the pouch young during this time (W. E. Poole, personal communication; Text-fig. 1a) and the decline in mammary gland weight after Week 34 corresponded to the time of weaning (Green, et al., 1980). However, there was considerable variation in weights after about Week 30 of lactation, which was probably due to several factors, including differences in the stage at which the individual pouch young were weaned and differences in the amount of milk stored in the gland at the time of death. Another useful way to examine the changes in mammary gland weights was to average the values from the various stages of lactation. For example, the mean \pm s.e.m. values for early ( $0-8$ weeks), mid- (9-25 weeks) and late (26-34 weeks) lactation and weaning (40-48 weeks) were $1 \cdot 3 \pm 0 \cdot 1 \mathrm{~g} .(n=12), 4 \cdot 0 \pm 0 \cdot 8 \mathrm{~g}(n=$ $8), 27.7 \pm 3.0 \mathrm{~g}(n=9)$ and $19.6 \pm 1.8 \mathrm{~g}(n=6)$ respectively.

The results for the degree of prolactin binding $/ \mu \mathrm{g}$ DNA in the suckled and non-suckled glands throughout lactation (Text-fig. 1b) give a measure of prolactin receptor numbers per cell. By 3 days after parturition there was no significant difference between the suckled and unsuckled glands. However, by 7 days the binding of prolactin to the suckled gland had almost doubled whereas it had halved in the unsuckled glands. By 3 weeks, the binding in the unsuckled glands had declined to the levels typica! of totally inactive glands (around $0.3 \times 10^{-16} \mathrm{~mol}$ prolactin/ $\mu \mathrm{g}$ DNA) while the amount of binding in the suckled glands had increased even more. Thereafter the binding to the suckled gland increased gradually up to around 6-8 $610^{-16} \mathrm{~mol}$ prolactin $/ \mu \mathrm{g}$ DNA by Week 12 of lactation and remained at this level until the end of the sampling period (Week 48). The slight decrease in binding between Weeks 28 and 34 was probably not significant as the level had increased again by Week 48 . The mean \pm s.e.m. values for the various stages of lactation (early, mid-, late and weaning as defined above) were $4 \cdot 3 \pm 0 \cdot 4(n=9) ; 7 \cdot 2 \pm 0 \cdot 3(n=8) ; 5 \cdot 2 \pm 0 \cdot 4(n=$ $8)$ and $6 \cdot 0 \pm 0 \cdot 2(n=2) \times 10^{-16} \mathrm{~mol}$ prolactin $/ \mu \mathrm{g}$ DNA respectively. Since there was a consider- 

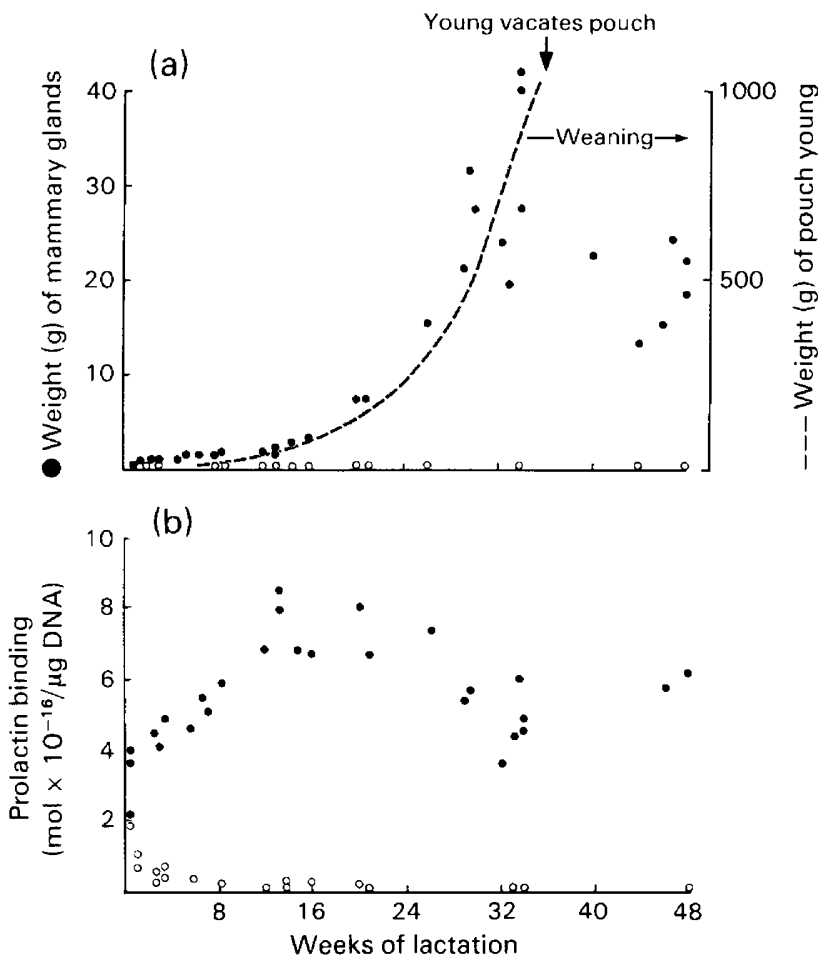

Text-fig. 1. The weight (a) and prolactin receptor binding measurements (b) of the lactating (O) and non-lactating $(O)$ mammary glands sampled during lactation in the tammar wallaby. Only one of the four glands in each animal was lactating and not all of the remaining 3 inactive glands in each animal were used in the study. Also shown in (a) is the weight (--) of an individual female pouch young (W. E. Poole \& S. M. Carpenter, unpublished data).

able increase in weight of the suckled gland up to Week 30 and the total DNA content per gram of mammary tissue was constant (at $1955 \pm 55 \mu \mathrm{g}$ DNA/g wet tissue) during this time, it can be concluded that, although the receptor concentration per cell did not increase significantly after Week 12, the total number of receptors in the suckled gland did increase because there was an

\section{PLATE 1}

Fig. 1. Section of an inactive mammary gland taken from an animal in reproductive quiescence. This gland weighed only $0.19 \mathrm{~g}$ and consisted of a small area of inactive glandular tissue surrounded by connective tissue.

Fig. 2. Section of a gland taken from an animal showing oestrous behaviour. The alveoli were distended with secretions and the amount of glandular tissue was greater than that found in inactive glands.

Fig. 3. Section of a lactating gland taken at 12 weeks of lactation. The alveoli had increased in number and were very distended with secretions. This suggests that the 3 -fold increase in weight of the gland during the first 12 weeks of lactation was due to an increase in the number of secretory cells and the amount of stored milk.

Fig. 4. Section of a gland taken at oestrus from one of the animals from which the corpus luteum had been removed. This gland was no heavier than any of the inactive glands and was similar in appearance with a small quantity of inactive glandular tissue surrounded by a relatively large amount of connective tissue. 

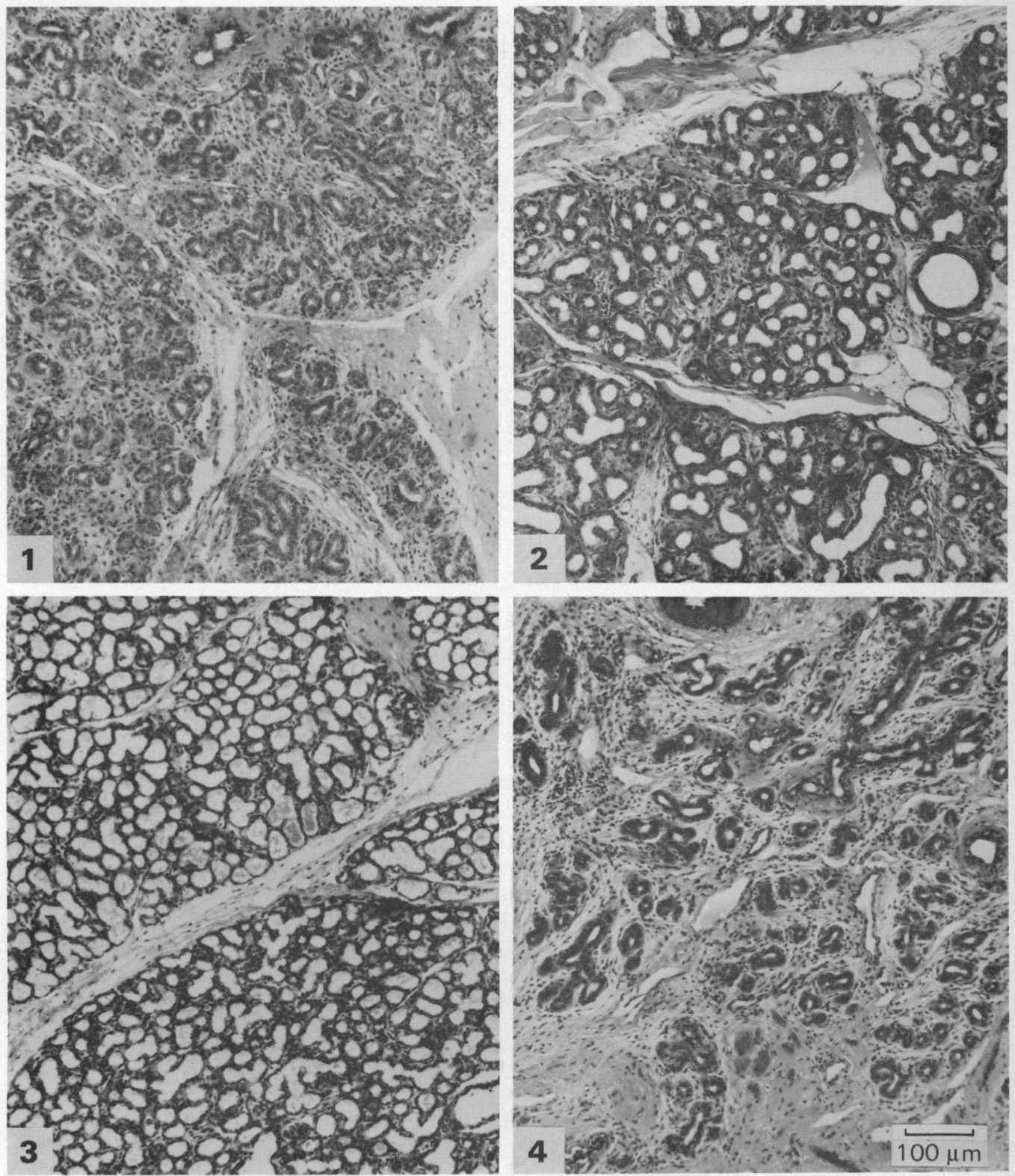

(Facing p. 144) 
increase in cell number. When the mammary gland weight was plotted on a logarithmic scale (Textfig. 2), the increase in weight of the suckled gland was linear up to Week 30 (slope $0 \cdot 047$; correlation coefficient 0.98 ), thereby demonstrating the exponential growth rate of the suckled gland. This plot also clearly illustrated the decline in weight of the unsuckled glands in the animals from about $1 \mathrm{~g}$ at parturition to about $0.2 \mathrm{~g}$ by Week 4 of lactation. In most cases, only one or two of the 3 inactive glands from each animal were weighed; some were not included as they were still obviously enlarged from a previous lactation.

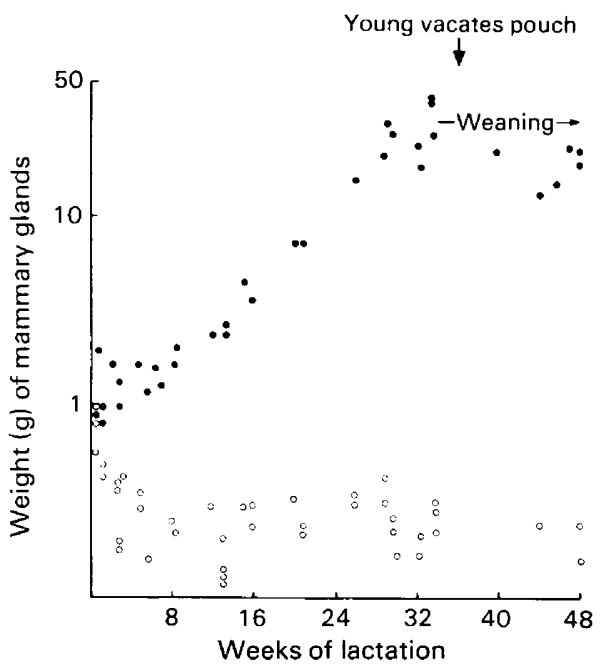

Text-fig. 2. The results shown in Text-fig. 1(a) plotted on a logarithmic scale. Note the exponential growth rate of the lactating gland $(O)$ to a maximum of around $40 \mathrm{~g}$ and decrease in weight of the non-lactating glands $(O)$ to a plateau of around $0.2 \mathrm{~g}$.

Histological examination of the tammar mammary glands revealed considerable morphological changes during lactation. Totally inactive glands (P1. 1, Fig. 1) collected from quiescent animals consisted of a small area of inactive glandular tissue surrounded by a large amount of connective tissue. The alveoli were small and showed no evidence of secretory activity. Unsuckled glands from lactating animals were similar in appearance and, at the light microscopical level, were indistinguishable from glands from quiescent animals.

At parturition and/or oestrus (Pl. 1, Fig. 2) the alveoli were distended, indicating some degree of secretory activity, and the connective tissue was less obvious. This suggested that the approximate doubling in weight of these glands seen at oestrus was due to the secretory products of the alveoli and to an increase in the number of secretory cells. This is in agreement with Findlay (1982) who observed an increase in the number of mitotic figures as birth/oestrus was approached.

During early lactation, when the glands were steadily increasing in weight, the alveoli became even more distended and there was an obvious increase in the number of secretory cells. Plate 1 , Fig. 3 shows the histological appearance of a mammary gland at Week 12 of lactation. This gland weighed $2.4 \mathrm{~g}$, while the 3 unsuckled glands from the same animal weighed around $0.2 \mathrm{~g}$ each. By this stage of lactation, the epithelial cells lining the alveoli were becoming squamous in appearance due to distension of the glands and ducts with milk. Although the lactating gland continued to increase in size up to 30-35 weeks, concomitant with a large increase in milk production, the morphological appearance of the glandular tissue did not show any further dramatic change. The large increase in the weight of the glands up to Week 35 appeared to be due to an increase in both the amount of tissue and the amount of stored milk. 
Mammary gland development during the oestrous cycle and pregnancy

The results in Text-fig. 3 show the increase in weight of the mammary glands during the cycle (28 days) and pregnancy ( 26 days) and demonstrate no significant difference between the pregnant and non-pregnant animals. Due to the small number of animals examined at parturition (2) compared to oestrus (5), it was not possible to apply an adequate statistical test to these weights. However, taking all the results together, it was fairly obvious that pregnancy had little effect on mammary gland development. This is in agreement with the original observations of O'Donoghue (1912) and Sharman (1962). The prolactin binding values for these glands also showed no discernible effect of pregnancy, with the binding increasing gradually in both groups of animals to reach a peak of $2.4 \times 10^{-16} \mathrm{~mol}$ prolactin $/ \mu \mathrm{g}$ DNA $(n=2)$ at parturition and $1.85 \pm 0.21 \times 10^{-16}$ $\mathrm{mol}$ prolactin $/ \mu \mathrm{g}$ DNA $(n=5)$ at oestrus.

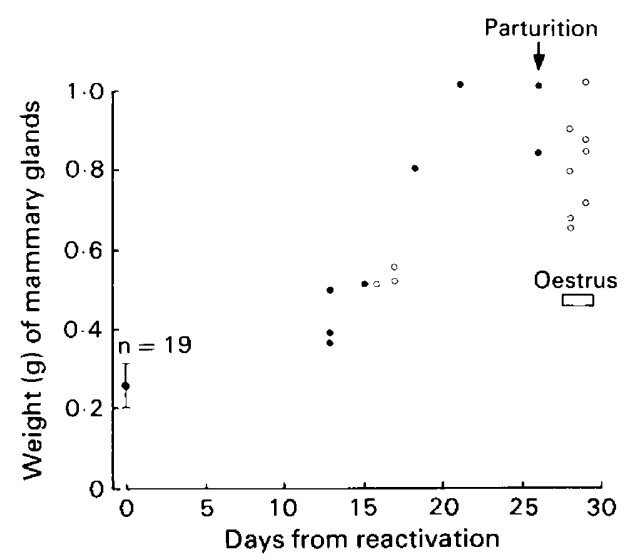

Text-fig. 3. The weight of individual mammary glands collected from several pregnant (O) and non-pregnant $(O)$ tammar wallabies. These animals had been in a state of reproductive quiescence for various lengths of time before 'reactivation' at Day 0 (see text for details). The figure at Day 0 is the mean \pm s.e.m. for 19 glands taken from quiescent animals. There was no detectable difference between the pregnant and non-pregnant animals.

\section{The effect of corpus luteum removal on mammogenesis}

Of the 8 animals from which the corpus luteum was excised only 3 returned to oestrus within a reasonable period of time ( 2 on Day 8 and 1 on Day 28). The other 5 animals were examined daily for at least 30 days after the operation without showing any signs of oestrus or mating. In addition, it was not possible to use all 4 glands from the 3 animals that did return to oestrus, since one gland was still enlarged from aprevious lactation and one gland was fixed whole for histology. This left a total of 8 glands from 3 animals which were weighed and measured in the prolactin receptor assay. A similar number of glands (8) were collected from 3 non-pregnant, unoperated animals on the day of oestrus for comparison. The effect of corpus luteum removal was clear; the weight $(0 \cdot 38 \mathrm{~g}$, range $0.19-0.78 \mathrm{~g})$ and prolactin receptor binding $\left(0.68 \times 10^{-16} \mathrm{~mol}\right.$ prolactin $/ \mu \mathrm{g}$ DNA; range $0 \cdot 26-1 \cdot 32$ $\times 10^{-16} \mathrm{~mol}$ prolactin $/ \mu \mathrm{g}$ DNA) were less than half that in the control group $(0 \cdot 82 \mathrm{~g}$, range $0 \cdot 66-1 \cdot 1$ $\mathrm{g}$; and $1.85 \times 10^{-16} \mathrm{~mol}$ prolactin $/ \mu \mathrm{g} \mathrm{DNA}$, range $1.05-3.14 \times 10^{-16} \mathrm{~mol}$ prolactin $/ \mu \mathrm{g}$ DNA, respectively). 


\section{Discussion}

The 200-fold increase in the weight of the tammar wallaby mammary gland from the inactive state $(0.2 \mathrm{~g})$ to full lactation $(40 \mathrm{~g})$ at Week 34 is remarkable by comparison with most eutherians. The manner in which this growth parallels the growth of the pouch young during this time illustrates the response of the gland to the growing needs of the young. This is a characteristic of all marsupials in which the young are born very immature and require a relatively long period of lactation with an ever increasing supply of milk (Smith, Brown \& Frith, 1969; Sharman, 1970). The present study has indicated that the increase in size of the lactating mammary gland was due to an increase in both the number of cells in the gland and also in the quantity of accumulated secretions. The change in prolactin receptor concentration per cell did not follow the same course as mammary gland weight and although receptor concentrations increased rapidly during the first 12 weeks of lactation, they remained essentially constant during the remainder of the sampling period (48 weeks). However, since the number of cells per lactating gland appeared to increase up to a maximum at 30-34 weeks, the total number of receptors per lactating gland also reached a peak at this time.

While these dramatic changes were taking place in the lactating mammary gland, the nonlactating glands in the same animal remained small and totally inactive. This has been reported in a number of marsupials (Sharman, 1962; Smith et al., 1969; Findlay, 1982) but has been examined in greater detail here by accurately weighing carefully dissected glands and by determining the prolactin receptor concentration in the mammary tissues from these glands. Both the weight and prolactin receptor concentration declined in the non-suckled glands after parturition and neither was influenced by the initiation of lactation in the fourth gland. This is a striking illustration of the importance of the local effects of the suckling stimulus and of milk withdrawal on the initiation and maintenance of lactation.

Prolactin levels fluctuate in the tammar wallaby, being low during the early stages of lactation and high towards the end of this period (Hinds \& Tyndale-Biscoe, 1982). This could, in part, be due to an increase in strength of the suckling stimulus as the pouch young increases in size. However, prolactin secretion also seems to be influenced by season (Tyndale-Biscoe \& Hinds, 1983) and it is possible that part of the increased prolactin levels late in lactation may be due to seasonal effects. Prolactin is necessary for successful lactation in the tammar (Hearn, 1974; Hinds \& TyndaleBiscoe, 1982), although the exact relationship between changes in plasma prolactin concentration and lactation remains unclear. Certainly the high levels of prolactin in late lactation have no stimulatory effect on the non-lactating glands, which is presumably due, in part, to these glands lacking prolactin receptors at this stage. The initial increase in receptor numbers in the suckled gland may be stimulated simply by the withdrawal of the accumulated secretions from the glands by the pouch young. Further withdrawal would then stimulate more secretory activity as well as cell growth and division and thus a further increase in receptor numbers. The increase in total prolactin receptor numbers would be expected to increase the sensitivity of the active mammary tissue to circulating prolactin.

This study has confirmed earlier work which indicated that marsupial mammary glands undergo a slight enlargement during the luteal phase of the oestrous cycle. This involved hypertrophy and hyperplasia and was associated with a significant increase in prolactin receptor numbers. Removal of the corpus luteum abolished the mammogenesis and prolactin receptor synthesis, even though the animals returned to oestrus. This suggests that luteal secretions, possibly progesterone, may be responsible for these changes.

The observation that pregnancy had no discernible effect on the degree of mammogenesis normally seen during the oestrous cycle confirmed that pregnancy is not a necessary prerequisite for successful lactation in this marsupial. This was in spite of the large peak in serum prolactin concentration that occurs just before parturition in the tammar (Hinds \& Tyndale-Biscoe, 1982) and which, in eutherians, appears to be necessary for mammary gland development and initiation of lactation (Kann \& Denamur, 1974; Karg \& Schams, 1974). 
I am most grateful to Dr C. H. Tyndale-Biscoe for his continuing interest, advice and criticisms during this study and to Carol Horn and Lyn Hinds for technical assistance.

\section{References}

Burton, K. (1956) A study of the conditions and mechanism of the diphenylamine reaction for the colorimetric estimation of deoxyribonucleic acid. Biochem. J. 63, 315-323.

Findlay, L. (1982) The mammary glands of the tammar wallaby (Macropus eugenii) during pregnancy and lactation. J. Reprod. Fert. 65, 59-66.

Green, B., Newgrain, K. \& Merchant, J. (1980) Changes in milk composition during lactation in the tammar wallaby (Macropus eugenii). Aust. J. biol. Sci. 33, 3542.

Griffiths, M., McIntosh, D.L. \& Leckie, R.M.C. (1972) The mammary glands of the red kangaroo with observations on the fatty acid components of the milk triglycerides. J. Zool., Lond. 166, 265-275.

Hearn, J.P. (1974) The pituitary gland and implantation in the tammar wallaby, Macropus eugenii. J. Reprod. Fert. 39, 235-241.

Hinds, L.A. \& Tyndale-Biscoe, C.H. (1982) Prolactin in the marsupial Macropus eugenii during the estrous cycle, pregnancy and lactation. Biol. Reprod. 26, 391398.

Kann, G. \& Denamur, R. (1974) Possible role of prolactin during the oestrous cycle and gestation in the ewe. $J$. Reprod. Fert. 39, 473-483.

Karg, H. \& Schams, D. (1974) Prolactin release in cattle. J. Reprod. Fert. 39, 463-472.

Merchant, J.C. \& Sharman, G.B. (1966) Observations on the attachment of marsupial pouch young to the teats and on the rearing of pouch young by foster-mothers of the same or different species. Aust. J. Zool. 14, 593-609.

O'Donoghue, C.H. (1912) The growth changes in the mammary apparatus of Dasyurus and the relation of the corpora lutea thereto. $Q$. $J l$ microsc. Sci. 57, 187234.

Sernia, C. \& Tyndale-Biscoe, C.H. (1979) Prolactin receptors in the mammary gland, corpus luteum and other tissues of the tammar wallaby, Macropus eugenii. J. Endocr. 83, 79-89.

Sharman, G.B. (1962) The initiation and maintenance of lactation in the marsupial, Trichosurus vulpecula. $J$. Endocr. 25, 375-385.

Sharman, G.B. (1970) Reproductive physiology of marsupials. Science, N.Y. 167, 1221-1228.

Sharman, G.B. \& Calaby, J.H. (1964) Reproductive behaviour in the red kangaroo, Megaleia rufa, in captivity. CSIRO Wildlife Res. 9, 58-85.

Smith, M.J., Brown, B.K. \& Frith, H.J. (1969) Breeding of the brush-tailed possum, Trichosurus vulpecula (Kerr) in New South Wales. CSIRO Wildlife Res. 14, 181-193.

Stewart, F. \& Tyndale-Biscoe, C.H. (1982) Prolactin and luteinizing hormone receptors in marsupial corpora lutea: relationship to control of luteal function. $J$. Endocr. 92, 63-72.

Tyndale-Biscoe, C.H. \& Hawkins, J. (1977) The corpora lutea of marsupials: aspects of function and control. In Reproduction \& Evolution, pp. 245-252. Eds J. H. Calaby \& C. H. Tyndale-Biscoe. Australian Academy of Science, Canberra.

Tyndale-Biscoe, C.H. \& Hinds, L.A. (1983) Seasonal patterns of circulating progesterone and prolactin and response to bromocriptine in the female tammar Macropus eugenii. Gen. comp. Endocrinol. 52 (in press).

Tyndale-Biscoe, C.H. \& Rodger, J.C. (1978) Differential transport of spermatozoa into the two sides of the genital tract of a monovular marsupial, the tammar wallaby (Macropus eugenii). J. Reprod. Fert. 52, 3743.

Tyndale-Biscoe, C.H., Hearn, J.P. \& Renfree, M.B. (1974) Control of reproduction in macropodid marsupials. J. Endocr. 63, 589-614.

Received 23 August 1983 